\title{
Case for diagnosis. Lichen myxedematosus ${ }^{\star}$
}

\author{
Priscila Regina Orso Rebellato ${ }^{1}$ \\ Nicole Iasmin Magario Tabuti ${ }^{3}$
}

\author{
Mauren Beatriz Frazon Carbonar ${ }^{2}$ \\ Graziela Junges Crescente Rastelli ${ }^{1}$
}

DOI: http:/ / dx.doi.org/10.1590/abd1806-4841.20165725

\section{CASE REPORT}

A 51-year-old male presented with multiple papules that had been present for one year. He reported difficulty moving his fingers and pain in his proximal interphalangeal articulation, which worsened with heat. He had suffered an acute myocardial infarction one month before and was on treatment for dyslipidemia.

Dermatological examination showed whitish and normochromic millimetric papules on his neck, back, hands, feet, abdomen, and in the inguinal region (Figures 1 and 2). In addition, his face and earlobes showed infiltration.

Histopathology found revealed mucin deposits and fibroblast proliferation in the reticular dermis, the hypodermis, and a mild perivascular lymphocytic infiltrate. The epidermis was mildly acanthotic, and the basal layer was normal as well as the hypodermis (Figures 3 and 4).

Protein electrophoresis showed a peak of gamma globulin of $21.8 \%(11.1 \%-18.8 \%)$ and of beta-2 microglobulin at 2,095 ng/ $\mathrm{ml}$ (normal values up to $2,000 \mathrm{ng} / \mathrm{ml}$ ). Other laboratory tests were unremarkable.

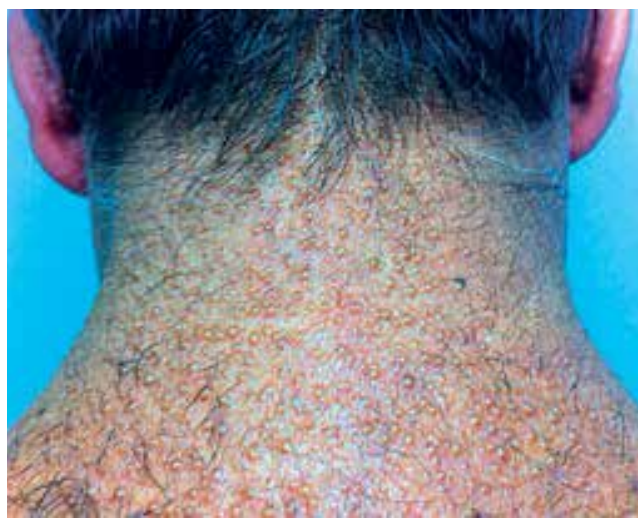

Figure 1:

Whitish and normochromic millimetric papules in the posterior cervical region

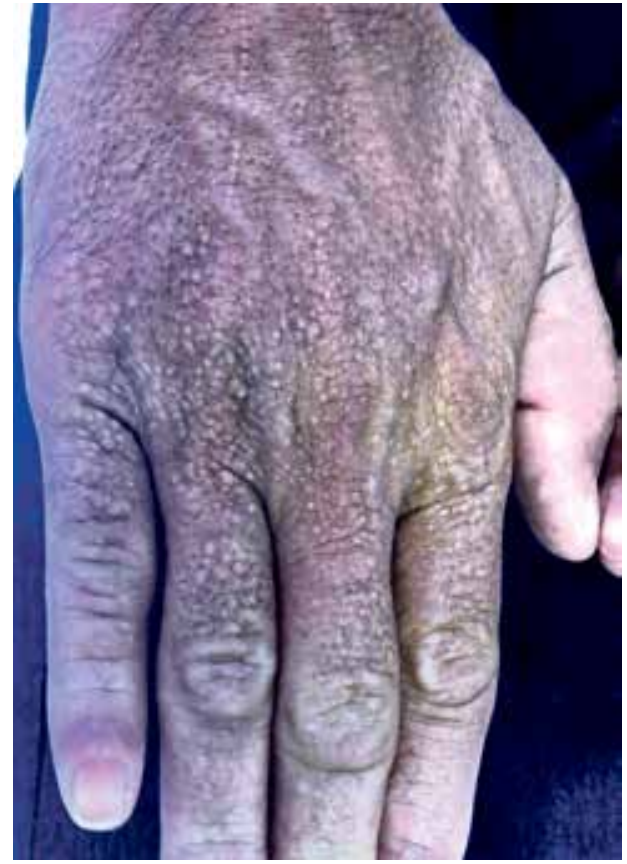

FIGURE 2:

Whitish and normochromic millimetric papules on the back of the right hand
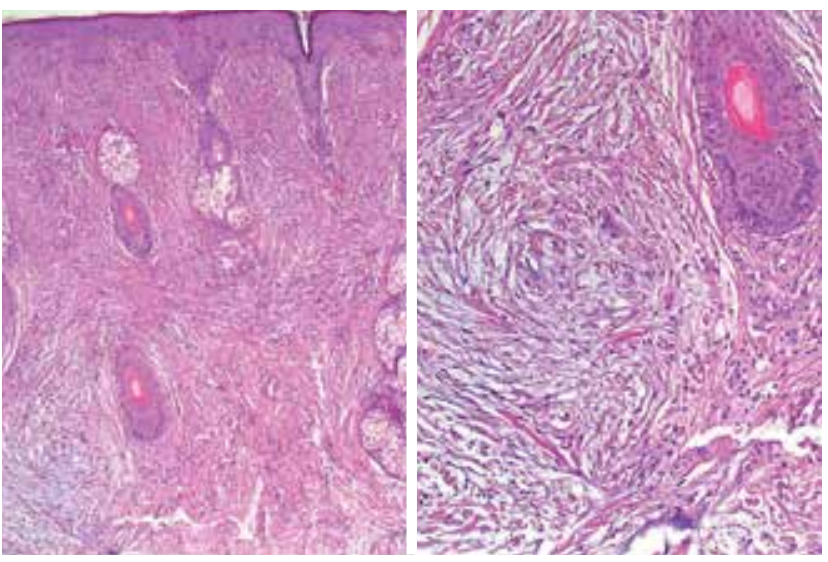

FIGURE 3: Characteristic triad: fusiform cells (fibroblasts) in the superficial and mid layer of the dermis, fibrosis, and pronounced mucin deposition (HE)

Received on 23.02.2016

Approved by the Advisory Board and accepted for publication on 12.06.2016

* Work performed at the Ambulatório do Hospital Universitário Evangélico de Curitiba - Faculdade Evangélica do Paraná (HUEC-Fepar) - Curitiba (PR), Brazil.

Financial Support: None.

Conflict of Interest: None.

Faculdade Evangélica do Paraná (Fepar) - Curitiba (PR), Brazil.

2 Universidade Positivo (UP) - Curitiba (PR), Brazil.

3 Universidade Federal do Paraná (UFPR) - Curitiba (PR), Brazil.

C2016 by Anais Brasileiros de Dermatologia 


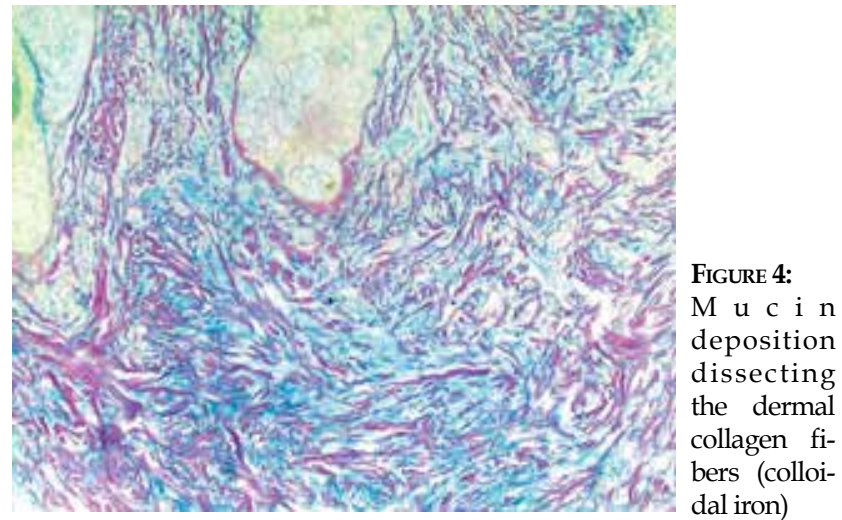

\section{DISCUSSION}

Scleromyxedema or lichen myxedematosus (LM) is a rare type of papular mucinosis, with a chronic and progressive course, chronic, progressive, of unknown etiology. It is commonly associated with monoclonal paraproteinemia ${ }^{1-3}$ and is characterized by papular lesions associated with erythema and thick, diffuse scleroderma-like changes. ${ }^{2}$ The normochromic or erythematous papules are stiff and grouped, ranging from $1 \mathrm{~mm}$ to $4 \mathrm{~mm}$. They are symmetrically arranged, primarily on the back of the hands and fingers, the extensor surface of the arms, the face, the upper torso, and the legs. Scalp and mucosae are not affected. ${ }^{1,4}$ They may coalesce, resulting in widespread induration of the skin and eventually leading to leonine facies and microstomia. ${ }^{1,2}$

In some cases, LM may be associated with multiple myeloma, acute leukemia, and T-cell lymphoma. ${ }^{1}$ Extracutaneous mani- festations include dermato-neural syndrome, myopathy, inflammatory polyarthritis, esophageal disorders, changes in the larynx and nerves, pulmonary disease, and heart and liver abnormalities. ${ }^{1,2}$ Cardiac abnormalities occur in $10 \%$ of cases, characterized by mucin deposition in the middle layer and adventitia of the myocardial vessels, as well as mucinous degeneration of the atheromatous plaques of the arteries. ${ }^{5}$ Association with systemic hypertension has also been reported..$^{5}$

The diagnosis is based on four criteria: generalized papular and sclerodermoid lesions; mucin deposition, fibroblast proliferation, and fibrosis in the histopathology; monoclonal gammopathy; and no thyroid disorders. ${ }^{6}$ The patient showed all four criteria.

Histological exam of the upper dermis shows a horizontal band of mucinous material between the round, stellate-shaped and irregularly distributed collagen fibers and fusiform fibroblasts, ${ }^{1,2}$ as well as dermal fibrosis. ${ }^{3}$

Differential diagnoses include systemic sclerosis, amyloidosis, scleredema, lichen nitidus, drug-related drug-related lichenoid eruptions, scleroderma, disseminated syringoma, pityriasis rubra pilaris, leprosy, and lichen tuberculid. ${ }^{2,3}$

there is no established treatment. ${ }^{2}$ Alkylating agent melphalan was considered a first-line treatment, but limited use due to its side effects. ${ }^{1-3}$

Other treatments described include cyclophosphamide, intralesional infiltration of hyaluronidase and triamcinolone, $\mathrm{CO} 2$ laser, methotrexate, cyclosporine, radiotherapy, thalidomide, plasmapheresis, 2'-deoxyadenosine (2-CD), systemic corticoid, chloroquine, intravenous immunoglobulin, retinoids, chemotherapeutic agents, and PUVA, but results may vary.

Abstract: Scleromyxedema or lichen myxedematosus is a rare papular mucinosis of chronic and progressive course and unknown etiology. It is commonly associated with monoclonal gammopathy and may show extracutaneous manifestations, affecting the heart, lung, kidney, and nerves. The diagnosis is based on four criteria: generalized papular and sclerodermoid lesions; mucin deposition, fibroblast proliferation, and fibrosis in the histopathology; monoclonal gammopathy; and no thyroid disorders. This article reports the case of a scleromyxedema patient with a recent history of acute myocardial infarction and monoclonal gammopathy.

Keywords: Mucinoses; Paraproteinemia, Scleromyxedema

\section{REFERENCES}

1. Martins GA, Abdala WG, Andrade DV. Escleromixedema associado a miocardiopatia. An Bras Dermatol. 2004;79:561-6.

2. Trindade Neto PB, Sales A0, Silva ACO, Nunes JCS. Escleromixedema: um caso tratado com prednisona oral. An Bras Dermatol. 2006;81:55-8.

3. Rongioletti F, Rebora A. Mucinoses. In: Bolognia J, Jorizzo JL, Schaffer JV. Dermatology. 3rd ed. Philadelphia: Elsevier; 2012. Vol 1, p.687.

4. Volpato MB, Jaime TJ, Proença MP, Gripp AC, Alves MFGS. Mucinose papulosa associada ao hipotireoidismo. An Bras Dermatol. 2010;85:89-92.

5. Morris-Jones R, Staughton RC, Walker M, Sheridan DJ, Rajappan K, Leonard J, et al. Lichen myxoedematosus with associated cardiac abnormalities. Br J Dermatol. 2001;144:594-6

6. Rongioletti F. Lichen myxedematosus (papular mucinosis): new concepts and perspectives for an old disease. Semin Cutan Med Surg. 2006;25:100-4

7. Serdar ZA, Altunay IK, Yasar SP, Erfan GT, Gunes P. Generalized papular and sclerodermoid eruption: Scleromyxedema. Indian J Dermatol Venereol Leprol. 2010;76:592.

\author{
MAILING ADDRESS: \\ Priscila Regina Orso Rebellato \\ Rua Luiz Leitner, 50 \\ Bairro Bigorrilho \\ 80710-390 - Curitiba - PR \\ Brazil \\ E-mail:prirebellato@yahoo.com.br
}

How to cite this article: Rebellato PRO, Carbonar MBF, Tabuti NIM, Rastelli GJC. Case for diagnosis. scleromyxedema. An Bras Dermatol. 2016;91(6):842-3. 